\title{
The Effect of Independence, Time Pressure, and Accountability, and Due Professional Care on Audit Quality Improvement
}

\author{
Eko Hariyanto ${ }^{1}$, Edi Joko Setyadi ${ }^{2}$, Annisa Ilma Hartikasari ${ }^{3}$ \\ \{ekoh0361@gmail.com¹, ej_setyadi@yahoo.co.id ${ }^{2}$, aihartikasari@gmail.com ${ }^{3}$ \} \\ Faculty of Economics and Business, Universitas Muhammadiyah Purwokerto
}

\begin{abstract}
The purpose of this study was to analyze the influence of independence, accountability, time pressure and due professional care on the improvement of audit quality. The analysis is carried out in two stages, first is testing the effect of independence, accountability, time pressure on audit quality improvement. Second, testing mediation effect of due professional care on that first effect. Data was collected using a questionnaire method using 38 samples. In this study, sample consists of Auditors who worked at the Public Accounting Firm in Central Java and had at least 2 years experience. All variables are measured on an ordinal scale. Data was analyzed using Structural Equation Modeling (SEM) using Partial Least Squares (PLS) program. The results showed that the independence and time pressure did not affect due professional care, while accountability had a positive effect on due professional care. Independence and accountability had a positive effect on audit quality, while time pressure did not affect audit quality. Due professional care cannot mediate the effect of independence, time pressure and accountability on audit quality.
\end{abstract}

Keywords: independence, accountability, time pressure, due professional care, audit quality.

\section{Introduction}

The financial statements provide an overview and information of the company's performance needed by internal and external parties as the basis for decision making. According to the FASB, a company's financial statements must have two important characteristics, namely relevance and can be reliable. Public Accounting Firms to carry out their functions are needed by auditors as executors in carrying out the services provided to provide relevant and reliable guarantees of the company's financial statements, so as to increase the confidence of the parties concerned related to the company. The auditor is given the trust of management and third parties to prove the financial statements presented by management are free from material misstatement. This trust must be maintained by showing professional performance $[1]$.

[2] explains that audit quality as a possibility that auditors will find and report violations that exist in the accounting system. Until now there are still doubts about public accountants by users of financial statements because of the scandal involving public accountants.

In this study there are several things that can affect audit quality, one of which is independence. According to [3], independence is one of the most important factors that must be owned by a Public Accountant to carry out an examination of financial statements. Auditing Standard Section 200.18 (SA: 2013) states that being independent for a public accountant means the auditor's ability to formulate an audit opinion without being able to be influenced.

Then another factor that affects audit quality is time pressure. The research of [4] explains that the time pressure experienced by the auditor in conducting audits also greatly affects audit quality. The high 
pressure when conducting an audit makes the auditor increasingly improve the efficiency of auditing so that often the audit conducted by the auditor is not always based on procedures and planning in accordance with applicable regulations.

The factor that influences the quality of subsequent audits is accountability. According to [5], accountability is the quality of the auditor's work that is influenced by the auditor's sense of responsibility in completing audit work and auditor independence, the auditor's probability to report violations that the auditor finds depends on the auditor's independence. Accountability is related to the attitude of openness (transparency) in relation to the way we are responsible for something in front of others.

According to [6], auditors are required to have high integrity, professional responsibility, prioritize community interests, work objectives, and always be able to develop the level of expertise and quality of services provided, in other words the auditor is responsible for the governance of an entity through oversight of strategies and obligations related to accountability, including oversight of the financial reporting process. According to [7] shows that accountability has a positive effect on audit quality. This is in line with research by

[8] which shows that accountability has a positive effect on audit quality.

Furthermore, the factors that influence audit quality in this study are due professional care. [1] argued that due professional care can be interpreted as a careful and careful attitude by thinking critically and evaluating audit evidence, being careful in assignments, not being careless when conducting examinations and having the determination to carry out responsibilities. According to [6], it shows that due professional care has a positive effect on audit quality. This is in line with the research of [9], showing that due professional care has a positive effect on audit quality. This is consistent with research conducted by [10], which shows that due professional care has a positive effect on audit quality, the results of the study are the same as the research conducted [1] which shows that due professional care has a positive effect on audit quality . According to [9], this means that the higher the caution of an auditor, the better the audit quality can be.

The users of financial statements really expect a right decision regarding the attitude towards other agencies/companies. The tool for obtaining information about other companies is the published financial statements. The financial statements will become more reliable if they have been audited by auditors, especially auditors from the Public Accountant Office. The insurance services provided by KAP are very trusted by the public. Therefore, the quality of audits produced by KAP auditors needs to be improved, this research will produce findings regarding the improvement of audit quality done by KAP auditors.

H1: Independence has a positive effect on Due Professional Care.

H2: Time pressure has a positive effect on Due Professional Care.

H3: Accountability has a positive effect on Due Professional Care.

H4: Independence has a positive effect on Audit Quality.

H5: Time pressure has a positive effect on Audit Quality.

H6: Accountability has a positive effect on Audit Quality.

H7: Due Professional Care has a positive effect on Audit Quality.

\section{Method}




\subsection{Population and Sample}

The population in this study are all auditors who work in public accounting firms in Central Java. The number of registered Public Accounting Firms is 15 KAPs, with 38 samples that can be returned and processed.

\subsection{Measurement and Definition of Variables}

Audit quality is the most important thing for users to pay attention to, because audit opinion will be the basis for investors and potential investors to make decisions. If the audited financial statements are not audited by qualified auditors, then the resulting opinion is also not qualified and will cause errors in the report users to make decisions [11]. The audit quality indicators according to [12] are as follows:(a). Compliance of audit with audit standard, (b) Quality of audit report.

Independence also means that there is honesty in the auditor to consider the facts and there are objective considerations that are not impartial to the auditor in formulating and expressing his opinion [4]. The independence indicators according to [12] are as follows: (a) Relationship with clients, (b) Independence of work implementation, (c) Report independence.

Time pressure is a condition where the auditor gets pressure from his place of work to be able to complete his task in accordance with a predetermined time. Time pressure consists of two kinds, namely time budget pressure and deadline time pressure. Unreasonable time pressure in achieving much time and cost budgets is proven as a potential from the behavior of audit quality decline [13]. The time pressure indicators according to [12] are as follows: (a) The auditor's attitude utilizes the audit time, (b) The auditor's attitude in decreasing audit quality.

Accountability is a psychological or psychiatric impulse which can influence the auditor to account for his actions as well as the impact caused by these actions on the environment the auditor conducts his activities. Individual responsibility does not only focus on the actions and decisions taken but also on the impact caused by the actions and decisions that have been taken. The accountability indicators according to [5] are as follows: (a) Motivation, (b) Social obligations, (c) Dedication to the profession.

Due professional care means careful and thorough professional skills. The third general standard requires independent auditors to be careful and thorough in carrying out their duties. The application of rigor and thoroughness is realized by conducting critical reviews at each level of supervision of the audit. Carefulness and equality regarding what the auditor does and how the perfection of the work produced. indicators of due professional care according to [14] as follows: (a) skepticism, (b) adequate confidence.

\subsection{Data Analysis and Hypothesis Testing}

All variables are measured on an ordinal scale. Data collection method with a questionare that is shared with respondents. Data obtained using Structural Equation Modeling (SEM). The program used is Partial Least Squares (PLS). 


\section{Results And Discussion}

Data that can be processed as many as 38 respondents with an overview of the data as follows in table 2 appendix. All indicators have smaller standard deviations than the average. Furthermore, the data were tested for validity and reliability. Testing with the Convergent validity and Discriminant validity models. The test results can be seen in table 3 in the appendix. Testing the outer model can be seen in Figure 1 which shows that all loading factors meet the requirements, which is a minimum of 0.5 .

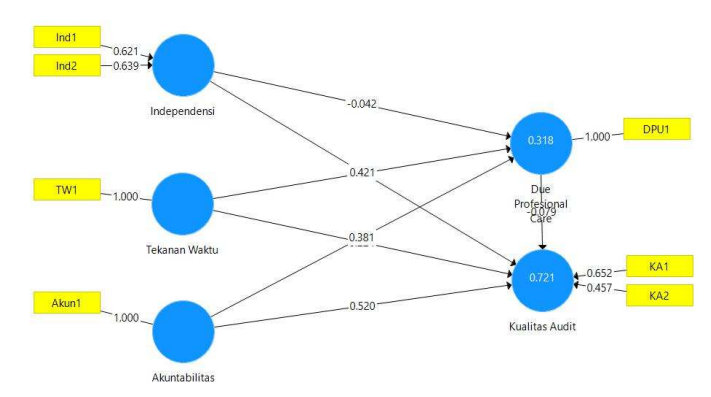

Fig.1. CFA reseach indicator

\subsection{Hypothesis Testing}

The following is the bootstrapping output of the PLS program for the path coefficients.

Table 1. Path Coefficients

\begin{tabular}{|c|c|c|c|c|c|}
\hline \multirow[t]{2}{*}{ Variabel } & \multirow{2}{*}{$\begin{array}{l}\text { Original } \\
\text { Sampel } \\
\text { (o) }\end{array}$} & Sampel & Standard & $\begin{array}{c}\mathrm{T} \\
\text { Statistic }\end{array}$ & \multirow{2}{*}{ P Values } \\
\hline & & Mean (M) & $\begin{array}{l}\text { Deviation } \\
\text { (STDEV) }\end{array}$ & $(|\mathrm{O} / \mathrm{STDEV}|)$ & \\
\hline $\begin{array}{l}\text { Akuntabilitas -> Due } \\
\text { Profesional Care }\end{array}$ & 0.356 & 0.361 & 0.152 & 2.347 & 0.010 \\
\hline $\begin{array}{l}\text { Akuntabilitas -> } \\
\text { Kualitas } \\
\text { Audit }\end{array}$ & 0.527 & 0.531 & 0.152 & 3.469 & 0.000 \\
\hline $\begin{array}{l}\text { Due Profesional care- } \\
> \\
\text { Kualitas Audit } \\
\text { Independen }\end{array}$ & -0.142 & -0.127 & 0.175 & 0.807 & 0.210 \\
\hline
\end{tabular}

Table 2. Path Coefficients 


\begin{tabular}{|c|c|c|c|c|c|}
\hline $\begin{array}{l}\text { Akuntabilitas -> } \\
\text { Due } \\
\text { Profesional Care }\end{array}$ & 0.356 & 0.361 & 0.152 & 2.347 & 0.010 \\
\hline $\begin{array}{l}\text { Akuntabilitas -> } \\
\text { Kualitas }\end{array}$ & & & & & \\
\hline Audit & 0.527 & 0.531 & 0.152 & 3.469 & 0.000 \\
\hline $\begin{array}{l}\text { Due Profesional } \\
\text { Care -> } \\
\text { Kualitas Audit }\end{array}$ & -0.142 & -0.127 & 0.175 & 0.807 & 0.210 \\
\hline $\begin{array}{l}\text { Thdependensi -> } \\
\text { Due }\end{array}$ & & & & & \\
\hline $\begin{array}{l}\text { Profesional } \\
\text { Care } \\
\end{array}$ & -0.007 & -0.020 & 0.205 & 0.034 & 0.487 \\
\hline $\begin{array}{l}\text { Independensi -> } \\
\text { Kualitas Audit }\end{array}$ & 0.446 & 0.443 & 0.151 & 2.945 & 0.002 \\
\hline $\begin{array}{l}\text { Tekanan Waktu } \\
\text {-> Due }\end{array}$ & & & & & \\
\hline $\begin{array}{l}\text { Profesional } \\
\text { Care }\end{array}$ & 0.513 & 0.393 & 0.363 & 1.414 & 0.079 \\
\hline $\begin{array}{l}\text { Tekanan Waktu } \\
\text {-> } \\
\text { Kualitas Audit }\end{array}$ & 0.273 & 0.185 & 0.207 & 1.317 & 0.094 \\
\hline
\end{tabular}

\section{H1: Independence influences Due professional care}

From the table above, it can be seen that the value of $t=0.034$, smaller than 1.96 , and the value of $\mathrm{p}$ value states is not significant ( $\mathrm{p}$ value $=0.487$ ).

H2: Time pressure affects Due professional care.

From the table above it can be seen that the value of $\mathrm{t}=1.414$, smaller than 1.96 , and the value of $\mathrm{p}$ value states is not significant ( $\mathrm{p}$ value $=0.079$ ).

H3: Accountability has a positive effect on Due professional care.

From the table above it can be seen that the value of $\mathrm{t}=2,347$, is greater than 1.96 , and the value of $\mathrm{p}$ value is significant ( $\mathrm{p}$ value $=0.010$ ).

H4: Independence influences audit quality

From the above table it can be seen that the value of $t=2.945$, is greater than 1.96 and the $p$ value is significant ( $\mathrm{p}$ value $=0.002$ ).

\section{H5: Time pressure influences Audit Quality}

From the table above it can be seen that the value of $\mathrm{t}=1.317$, smaller than 1.96 , and the value of $\mathrm{p}$ value states is not significant ( $\mathrm{p}$ value $=0.094)$

\section{H6: Accountability influences audit quality}

From the table above it can be seen that the value of $t=3.469$, is greater than 1.96 and the value of $\mathrm{p}$ value is significant ( $\mathrm{p}$ value $=0,000$ ). 
H7: Due professional care has an effect on audit quality.

From the above table it can be seen that the value of $\mathrm{t}=0.807$, smaller than 1.96 , and the value of $\mathrm{p}$ value states is not significant ( $\mathrm{p}$ value $=0.210$ ).

\subsection{Discussion}

1 Due Professional Care Variable noinfluences Audit Quality. This shows that Due Professional Care does not mediate the variables of independence, time pressure and accountability. Contrary to research conducted by [1] which states that due professional care has a positive effect on audit quality. In the research [1] tested directly, not as mediation.

2 Accountability has a positive effect on Audit Quality. This is in line with research on accountability conducted by Burhanudin [5] which shows the results that accountability has a positive effect on audit quality as well as research conducted by [6] states that accountability has a positive effect on audit quality.

3 Independence influenced Audit Quality. The results of this study are in line with research conducted by [15] reveals that independence has a positive influence on audit quality. Neither research from [3] also revealed that independence had a positive effect on audit quality.

4 Time pressure does not affect audit quality. Other studies have stated that time pressure negatively affects audit quality. As research by [12] states that time pressure has a negative effect on audit quality, this shows that the higher the time pressure applied to the auditor, the worse the audit quality will be.

5 Accountability has a positive effect on Due professional care. Time pressure and independence do not affect Due professional care. Research on the factors that directly affect Due Professional Care has not been found. Research [16], Independence has no effect on Due professional care. The due professional care variable in this study cannot moderate the relationship between independence, audit planning, audit supervision, accountability and integrity with audit quality at the Public Accounting Firm in Medan.

\section{Conclution}

From the results of the analysis it can be concluded as follows: independence and time pressure do not affect due professional care, while accountability has a positive effect on due professional care.Independence and accountability variables have a positive effect on audit quality, while time pressure does not affect audit quality. Due professional care cannot mediate the effect of independence, time pressure and accountability on audit quality.

\section{References}

[1] Wiratama,W.J dan Budiartha, Ketut. 2015. Pengaruh Independensi, Pengalaman Kerja, Due Professional Care dan Akuntabilitas terhadap Kualitas Audit. E-jurnal Akuntansi Universitas Udayana. Vol.10, No.1 , Hal: 91 106.

[2] De Angelo, L.E. 1981. Auditor Size and Audit Quality. Journal of Accounting and Economics 3 (1981) 183199. 
[3] Suardinatha, M.H dan Wirakusuma, M.G. 2016. Pengaruh Independensi dan Professionalisme terhadap kualitas audit. E-Jurnal Akuntansi Universitas Udayana. Vol. 17, No. 3. Desember (2016) Hal: 2503-2530.

[4] Shintya Agneus, Nuryatno Muhammad, Oktaviani.A.A. 2016. Pengaruh Kompetensi, Independensi dan Tekanan Waktu Terhadap Kualitas Audit. Seminar Nasional Cendekiawan. ISSN (E) : 2540-7589.ISSN (P) : 2460-8696.

[5] Burhanudin, Muhammad Alifzuda.2017. Pengaruh Akuntabilitas dan Independensi Auditor terhadap Kualitas Audit. Jurnal Profita Edisi 6.

[6] Vidyantari, Putu K dan Suputra, I Dewa G.P. 2018.Pengaruh Due Profesional Care, Akuntabilitas dan Kecerdasan Emosional terhadap Kualitas Audit. E-Jurnal Akuntansi Universitas Udayana. Vol.22, No.3. Hal: 2399-2429.

[7] Saripudin, Herawaty N, Rahayu. 2012. Pengaruh Independensi Pengalaman, Due Professional Care dan Akuntabilitas terhadap Kualitas Audit.E-Jurnal Binar Akuntansi. Vol. 1, No.1.

[8] Purwanda, Eka dan Harahap, E.A. 2015. Pengaruh Akuntabilitas dan Kompetensi terhadap Kualitas Audit. Jurnal Akuntansi/Volume XIX, No. 03 Hal: 357-369.

[9] Novela Tri.T, Sukarmanto Edi, Maemunah Mey. 2017. Pengaruh Due Professional Care, Tekanan Waktu, dan Akuntabilitas terhadap Kualitas Audit. Prosiding Akuntansi. ISSN:2460-6561.

[10] Fitria, Marisa. 2016. Pengaruh Tekanan Waktu, Due Professional Care, dan Etika Auditor terhadap Kualitas Audit. JOM Fekon Vol.3 No.1.

[11] Fachruddin Wan, Bahri Syamsul, Pribadi Angelia.2017. Analisis Faktor yang Mempengaruhi Kualitas Audit dengan Prosedur Audit Sebagai Pemesiasi. Jurnal Ilman, Vol.5, No.2. Hal :1-13. 
[12] Pikirang Julita, Sabijono Harijanti, Wokas H.R.N . 2017. Pengaruh Tekanan Waktu, Independensi dan Etika Auditor terhadap Kualitas Audit. E-jurnal Akuntansi Universitas Udayana. Vol.10, No.1, Hal:91106.

[13] Rizal, N dan Liyundira,F.S. 2016. Pengaruh Tekanan Waktu dan Independensi terhadap Kualitas Audit.Jurnal Penelitian Ilmu Ekonomi WIGA Vol. 6 No. 1 Hal: 45 - 52.

[14] Singgih, Elisha Muliani dan Icuk Rangga Bawono. 2010. Pengaruh Independensi Pengalaman,Due Professional Care dan Akuntabilitas terhadap Kualitas Audit.SNA XIII UJSP. Purwokerto.

[15] Wicaksono, Monot. 2015. Pengaruh Kompetensi dan Independensi terhadap Kualitas Audit. Jurnal Akuntansi dan Pajak. VOL. 15 NO. 02.

[16] Hasibuan, Khairul Amri, 2019, Analisis Faktor-Faktor yang Mempengaruhi Kualitas Audit dengan Due Professional Care Sebagai Variabel Moderating pada Kantor Akuntan Publik di Medan, tesis, Magister Akuntansi, USU. 